\title{
Scrapie diagnosis in a goat and four Santa Inês sheep from the same herd in Brazil
}

[Diagnóstico de scrapie em um caprino e quatro ovinos Santa Inês de um mesmo rebanho no Brasil]

\section{J.S. Leal ${ }^{1}$, G.L.F. Correa ${ }^{1}$, .G.S. Boos ${ }^{1}$, M.V. Bianchi ${ }^{1}$, F.M. Boabaid ${ }^{1}$,} R.F.F. Lopes ${ }^{2}$, D. Driemeier ${ }^{1}$

\author{
${ }^{1}$ Faculdade de Veterinária - Universidade Federal do Rio Grande do Sul - UFRGS - Porto Alegre, RS \\ ${ }^{2}$ Instituto de Ciências Básicas da Saúde - UFRGS - Porto Alegre, RS
}

\begin{abstract}
Scrapie is a fatal and progressive transmissible spongiform encephalopathy (TSE) of natural occurrence in sheep and goats. The suspicion of scrapie may be based on clinical signs; however, the detection of pathological features of the prionic protein $(\operatorname{PrP})$ in target tissues is necessary to diagnose the disease. The presence of an abnormal protein form $\left(\mathrm{PrP}^{\mathrm{Sc}}\right)$ in lymphoreticular and nervous tissues is an important characteristic in diagnosis. This paper reports a case of scrapie in a flock of 55 Suffolk crossbred sheep, 19 Santa Inês sheep and 21 goats in the Mato Grosso state, midwestern Brazil. The animals were euthanized after the confirmation of a scrapie case with clinical signs in a Suffolk sheep in the same farm. Samples of brainstem at the level of the obex and lymphoid issues like palatine tonsils, mesenteric lymph nodes, third eyelid fixed in formalin $10 \%$ were processed for histological examination. Histological examination with hematoxylin and eosin did not show any microscopic changes in samples. Immunohistochemistry (IHC) examination to detect anti-prion $\operatorname{PrP}^{\mathrm{Sc}}$ was performed in lymphoid tissues. Scrapie diagnosis was confirmed based on $\mathrm{IHC}$ positive results for $\mathrm{PrP}^{\mathrm{Sc}}$ in lymphoid tissues of a crossbreed goat and four Santa Inês sheep, without any clinical scrapie signs. IHC showed positive staining in at least three lymphoid germinal centers in goat mesenteric lymph node, palatine tonsil, and third eyelid samples. The mesenteric lymph node, and tonsil samples of all sheep showed positive immunostaining, and only one sheep showed positive staining in lymphoid follicles in the third eyelid. Scrapie diagnosis using IHC in fixed samples of lymphoreticular tissue is technically feasible to detect the disease in both goats and sheep, as a form of pre-clinical diagnosis. The results indicate that the herd was infected by a sheep coming from another herd where scrapie had been diagnosed before.
\end{abstract}

Keywords: scrapie, prion, diseases of small ruminants, immunohistochemistry, lymphoid tissues

\section{RESUMO}

Scrapie é uma encefalopatia espongiforme transmissível (EET) progressiva e fatal de ocorrência natural em ovinos e caprinos. A suspeita de scrapie é baseada nos sinais clínicos, porém a manifestação patológica da proteína priônica $(\operatorname{PrP})$ nos tecidos-alvo é necessária para a confirmação da doença. A presença de uma forma anormal da proteína $\left(\mathrm{PrP}^{S c}\right)$ em tecido linforreticular e tecido nervoso constitui uma característica importante para o diagnóstico. Este trabalho é o relato de um foco de scrapie ocorrido em rebanho com 55 ovinos mistos Suffolk, 21 caprinos e 19 ovinos Santa Inês, na região Centro-Oeste do Brasil. Os animais foram eutanasiados após a confirmação de um caso de scrapie com sinais clínicos em um ovino Suffolk nessa propriedade. Amostras de tronco cerebral na altura do obex e tecidos linfoides, que incluíram tonsilas, linfonodos mesentéricos e tecido linfoide da terceira pálpebra foram processados para exame histológico. O exame histológico utilizando a coloração de hematoxilina e eosina não revelou a presença de alterações microscópicas nos tecidos examinados. O diagnóstico de scrapie foi confirmado com base nos resultados positivos de imuno-histoquímica (IHQ) para $\operatorname{PrP}^{S C}$ nos

Recebido em 12 de setembro de 2014

Aceito em 7 de julho de 2015

E-mail: julianoob@gmail.com 
tecidos linfoides de um caprino sem raça definida e quatro ovinos da raça Santa Inês, sem sinais clínicos de scrapie. A IHQ apresentou marcação positiva em pelo menos três centros linfoides na tonsila, terceira pálpebra e linfonodo mesentérico do caprino. Em todos os ovinos, a IHQ revelou marcação positiva nos folículos linfoides da tonsila palatínica e linfonodo mesentérico; a marcação positiva nos folículos linfoides da terceira pálpebra só foi observada em um dos ovinos. Este trabalho demonstra a importância da utilização de tecido linforreticular para o diagnóstico pré-clínico de scrapie através de IHQ e é tecnicamente viável em ovinos e caprinos. Os resultados indicam que os animais foram contaminados por um ovino oriundo de um rebanho que apresentava casos clínicos de scrapie.

Palavras-chave: scrapie, príon, doenças de pequenos ruminantes, imuno-histoquímica, tecidos linfoides

\section{INTRODUCTION}

Scrapie is a transmissible spongiform encephalopathy (TSE) that occurs in sheep and goats, but rare cases have been reported in goat herds (Sofianidis et al., 2006). The disease has been recorded for over 250 years, though with no cases of transmission to humans (Vaccari et al., 2009). Animals affected by this low-progression, fatal disease may present ataxia, hyperthermia, tremors, pruritus and general wasting, although clinical signs may vary within a wide spectrum and are not always evident upon clinical examination (Sofianidis et al., 2006; Konold et al., 2010).

In goats, when the signs are observed, they are manifested as regurgitation of the ruminal content, which is regarded as an initial-stage sign of the disease (Sofianidis et al. 2006). Microscopically, astrocytosis is a common finding in goats presenting scrapie, though no association with vacuole changes has been established (Sofianidis et al., 2006), unlike most sheep scrapie cases (Konold et al., 2010).

Suspected scrapie cases may be based on the observation of clinical signs, and the pathological manifestation of prionic protein $(\mathrm{PrP})$ in target tissues is required to confirm diagnosis of TSE (Sofianidis et al., 2006). The presence of an abnormal form of the protein $\left(\mathrm{PrP}^{\mathrm{Sc}}\right.$, where $\mathrm{Sc}$ stands for scrapie) in lymphoreticular tissues, such as spleen, tonsils and lymph nodes, and nervous tissue is an important finding in diagnosis as well (O'Rourke et al., 2002; Furr et al., 2011; Leal et al., 2012 ).

In Brazil, positive scrapie cases have been reported (Leal et al.; 2012) and some research has investigated the susceptibility of ovine herds (Lima et al., 2007; Santos et al., 2012).
The susceptibility of ovine herds is largely defined by the genotype of animals. In scrapie, this susceptibility is determined mostly by the genotypes of the gene sequence that codifies for protein PrP, since there are several polymorphisms that affect the conversion of the cellular protein $\mathrm{PrP}^{\mathrm{C}}$ to its pathological form $\mathrm{PrP}^{\mathrm{Sc}}$. In spite of that, it is not possible to consider the existence of only one prion form in sheep, since several prion strains distinguishable based on their pathological and biochemical characteristics have been detected, and may affect genotypes distinctively (Jeffrey e Gonzalez, 2007; Mitchell et al., 2010; White et al., 2012).

The aim of this work is to report the occurrence of scrapie in a sheep and goat mixed herd in the state of Mato Grosso, midwestern Brazil, through immunohistochemistry (IHC) analysis of lymphoid tissues.

\section{CASE REPORT}

In 2007, a sheep and goat mixed herd composed of 95 animals was examined for the presence of $\mathrm{PrP}^{\mathrm{Sc}}$ in a farm in Mato Grosso state. In 2006, a scrapie case was diagnosed based on clinical signs in one Suffolk ram in this farm. Previously, in 2001 the farm owner had purchased 118 sheep (109 females and nine males) from a positive herd in the state of Paraná. The clinical manifestation and diagnosis of scrapie in one Suffolk sheep prompted the sacrifice of the herd reared in the property.

The mixed herd was formed by 95 animals, of which 55 were crossbred Suffolk sheep, 19 were Santa Inês sheep, and 21 were mixed bred goats. Samples of lymphoid tissues such as palatine tonsils, mesenteric lymph nodes, and third eyelid, and brainstem at the level of the obex, fixed in formalin $10 \%$ were analyzed by the 
Setor de Patologia Veterinária, at Universidade Federal do Rio Grande do Sul (SPV-UFRGS, Veterinary Pathology Service, Federal University of Rio Grande do Sul), Brazil.

After that, the samples were embedded in paraffin, cut in $3 \mu \mathrm{m}$-thick sections and stained by hematoxylin and eosin (HE). Additional sections were placed on StarFrost ${ }^{\circledR}$ adhesive slides (Light Labs, Dallas, USA) and examined according to the immunohistochemical protocol for $\operatorname{PrP}^{\mathrm{Sc}}$. The anti-prion immunohistochemical technique was carried out according to O'Rourke et al. (2002).

Anti-prion monoclonal antibodies F89/160.1.5 and F99/97.6.1 (VMRD, Pullman, USA) were added as a 1:500 solution and sections were incubated at $4^{\circ} \mathrm{C}$ in a humid chamber for $12 \mathrm{~h}$ (Leal et al., 2012).
Of the 118 animals purchased in 2001 from the farm in Paraná state, 32 sheep were still in the mixed herd of 95 animals in 2007. Histopathological analysis by HE staining did not reveal the presence of microscopic changes in the lymphoid tissues and obex. However, IHC examination revealed that ten of these remaining sheep had a positive diagnosis for scrapie. Six were Suffolk sheep (3-year-old ewes) and four were Santa Inês sheep (three 3-year-old ewes and one 4-year-old ram). Also, one female goat of approximately 1 year of age of mixed breed, that did not present clinical signs and was native tothe property, was diagnosed with scrapie.

In the goat, positive immunoreaction for $\operatorname{PrP}^{\mathrm{Sc}}$ was observed in at least three lymphoid follicles of the palatine tonsils, mesenteric lymph node and lymphoid tissue of third eyelid. PrP aggregates were observed within germinal centers of the lymphoid follicles (Fig. 1).

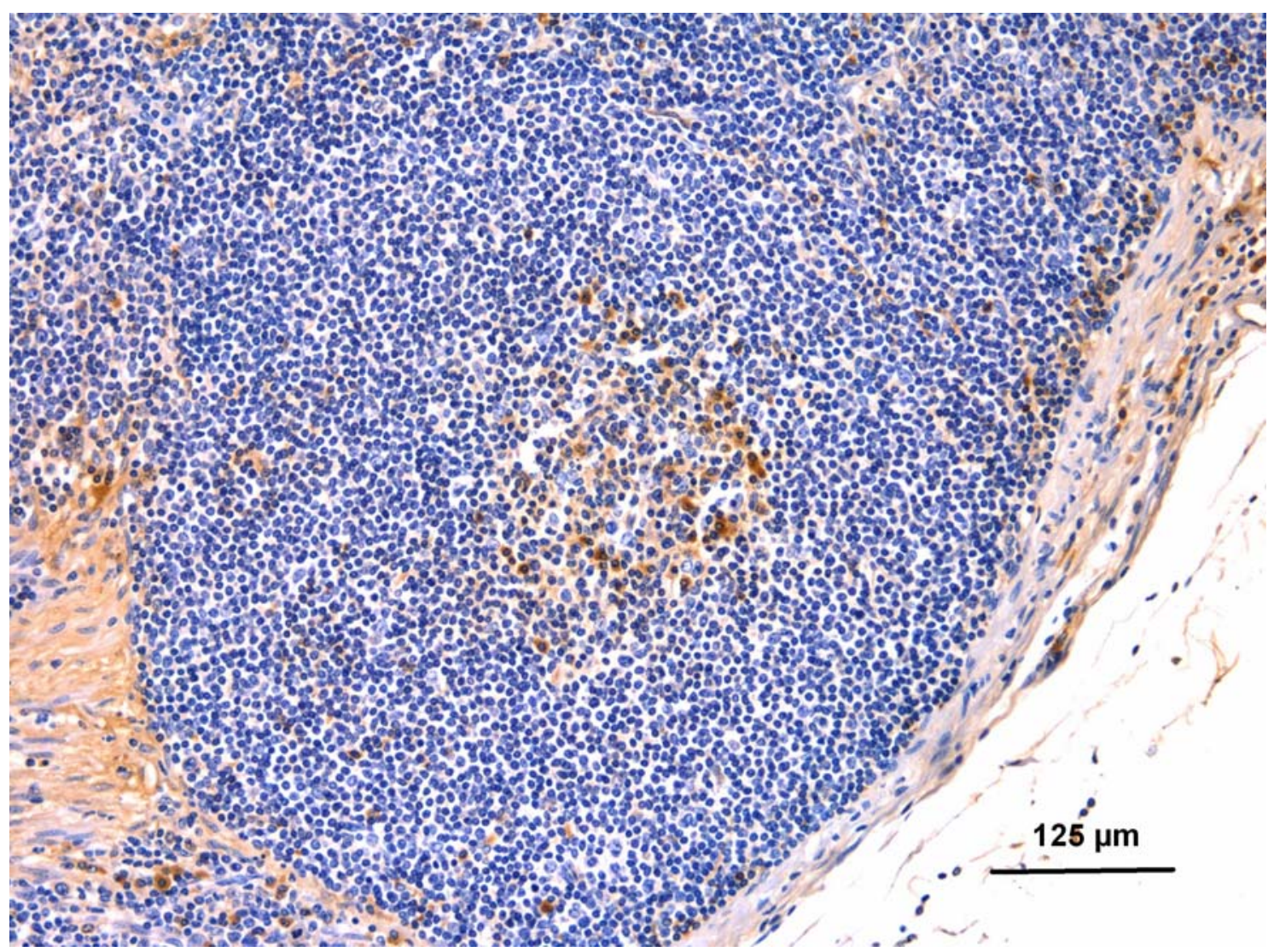

Figure 1. Immunohistochemistry to diagnose scrapie in a histologic section of the mesenteric lymph node of one goat. Lymphoid follicle with immunoreactivity for $\mathrm{PrP}^{\mathrm{Sc}}$ in the germinative center. [Magnification: 400x]. 


\section{DISCUSSION}

In all $\mathrm{PrP}^{\mathrm{Sc}}$ positive sheep, immunoreaction was observed in mesenteric lymph nodes and in palatine tonsils. Positive immunoreaction in the third eyelid was observed only in samples collected from the ram. Also, $\operatorname{PrP}$ aggregates were observed within germinal centers of the lymphoid follicles.

The insidious character of scrapie, its long latency, and the incurring loss of infected sheep due to secondary diseases before clinical signs of the disease unfold have resulted in the failure of control strategies, and have a considerable negative impact on sheep farming. The importance of development of pre-clinical diagnostic techniques has been demonstrated (O'Rourke et al., 2002; Leal et al., 2012). In goats, monitoring of clinical signs and diagnosis of scrapie are relatively recent (Vaccari et al., 2009). The occurrence of scrapie is lower in goats than in sheep (Sofianidis et al., 2006; Sofianidis et al., 2008), which culminates in less research in this species (Vaccari et al., 2009), and the disease usually occurs when animals cohabit with infected sheep (Konold et al., 2010). In Brazil, between 90 to $95 \%$ of the small ruminant herds have sheep and goat mixed production systems, practiced in a consortium with several perennial or annual crops. Usually, these extensive animal production systems are applied without using appropriate management and sanitary techniques and practices (Costa et al., 2008).

The potential to transmit scrapie usually develops in sheep between 7 and 30 months of age, though young animals are more susceptible to the disease, when compared to adults (O'Rourke et al., 2002; Mitchell et al., 2010). According to Sofianidis et al. (2006), in goats the relationship between lesions, $\operatorname{PrP}^{\mathrm{Sc}}$ deposition and age has not been examined, but the majority of the goats showing symptoms of the disease were older than 2 years of age. The fact that herds usually are large and that animals are often purchased from different farms is a major aspect in the spread of the disease. Also, the introduction of scrapie-free animals in infected herds is responsible for the horizontal transmission of the disease, even across adult animals (Jeffrey e Gonzalez, 2007).
In goats and sheep, the histopathological and immunohistochemical profile of the disease is ruled by the PrP genotype and age of animals (Sofianidis et al., 2006, Mitchell et al., 2010); however, the direct association with the presence or absence of clinical signs has yet to be proved. This means that a clear-cut relationship between clinical signs, histopathology findings and $\operatorname{PrP}$ genotype remains to be established (Sofianidis et al., 2006; Sofianidis et al., 2008).

The immunohistochemical diagnosis reported here for the goat has been previously described (White et al., 2012), and it is similar to what is observed in scrapie infected sheep (O'Rourke et al., 2002; Leal et al., 2012). Thus, it is presumed that scrapie in goats may show the same pathogenic dynamic as in sheep, since animals showing no clinical signs have a positive reaction to IHC in lymphoid tissues (Leal et al., 2012). The clinical sings related to suspected cases identification (tremor, hair loss, ataxia and scratch response testing) are highly specific, but most cases of scrapie have not been detected with these parameters. This is expected, since it was previously shown that post-mortem tests are superior to clinical examination in animal herds affected by scrapie, even if limited to brain examination (Konold et al., 2010). Contrary to the TSE in cattle, where the detection of PrP is basically restricted to the central nervous system, in small ruminants the $\operatorname{PrP}$ may be present in lymphoreticular tissues (tonsil, third eyelid and rectal mucosa) that are accessible in the live animal (Konold et al., 2010). The limphoreticular tissue examination of live animals using IHC is an important tool in subclinical cases (Leal et al., 2012).

The present study also reports the diagnosis of scrapie in four Santa Inês sheep. To date, research with this breed has identified polymorphisms in the PRNP gene, which enables the identification of resistant or susceptible animals to the disease (Lima et al., 2007; Santos et al., 2012), but no case had been reported before the present study. These authors identified both resistant and susceptible genotypes in the Santa Inês breed.

This research shows that IHC is a valuable tool to diagnose scrapie in lymphoreticular tissues fixed in formalin, of both sheep and goat. Active 
scrapie surveillance based on consistent herd identification, inspection and abattoir likewise stands as a suitable measure in TSE control strategies.

Further studies on the occurrence of scrapie in goats with clinical manifestations of the disease and on mixed goat and sheep farming methods should be conducted to confirm the outcomes of such interactions and the influence of these methods on the disease's causal agent.

\section{ACKNOWLEDGEMENTS}

The authors are grateful to Ministério da Agricultura Pecuária e Abastecimento (MAPA) for the collection of samples, and especially to Donizeti Pereira Mesquita, Veterinary Doctor, Serviço de Sanidade Animal (SSA/MT).

\section{REFERENCES}

COSTA, R.R.; ALMEIDA, E.C.; PIMENTA FILHO, E.C. et al. Caracterização do sistema de produção caprino e ovino na região semi-árida do estado da Paraíba, Brasil. Arch. Zootec., v. 57, p. 195-205, 2008.

FURR, A.; KNUDSEN, D.; HILDRETH, M.B.; YOUNG, A.J. Enhancement of immunohistochemical staining of scrapie proteins and immune cells within lymph nodes of early scrapie-infected sheep. J. Immunol. Methods, v.371, p.1-7, 2011.

JEFFREY, M.; GONZÁLEZ, L. Classical sheep transmissible spongiform encephalopathies: pathogenesis, pathological phenotypes and clinical disease. Neuropathol. Appl. Neurobiol., v.33, p.373-394, 2007.

KONOLD, T.; BONE, G.E.; PHELAN, L.J. et al. Monitoring of clinical signs in goats with transmissible spongiform encephalopathies. BMC Vet. Res., v.6, p.13, 2010.
LEAL, J.S.; CORREA, G.L.F.; DALTO, A.G.C. et al. Utilização de biopsias da terceira pálpebra e mucosa retal em ovinos para diagnóstico de scrapie em uma propriedade da Região Sul do Brasil. Pesqui. Vet. Bras., v.32, p.990-994, 2012.

LIMA, A.C.; BOSSERS, A.; SOUZA, C.E. et al. PrP genotypes in a pedigree flock of Santa Inês sheep. Vet. Rec. v.160, p.336-337, 2007.

MITCHELL, G.B.; O'ROURKE, K.; HARRINGTON, N.P. et al. Identification of atypical scrapie in Canadian sheep. J. Vet. Diagn. Invest., v.22, p.408-411, 2010.

O'ROURKE, K.I.; DUNCAN, J.V.; LOGAN, J.R. et al. Active surveillance for scrapie by third eyelid biopsy and genetic susceptibility testing of flocks of sheep in Wyoming. Clin. Diagn. Lab. Immunol. v.9, p.966-971, 2002.

SANTOS, C.R.; MORI, E.; LEÃO, D.A.; MAIORKA, P.C. Genotipagem de polimorfismos no gene prnp em ovinos da raça Santa Inês no Estado de São Paulo. Pesqui. Vet. Bras. v.32, p.221-226, 2012.

SOFIANIDIS, G.; PSYCHAS, V.; BILLINIS, C. et al. Histopathological and immunohistochemical features of natural goat scrapie. J. Comp. Pathol., v.135, p.116-129, 2006.

SOFIANIDIS, G.; PSYCHAS, V.; BILLINIS, C. et al. Atypical PrPsc distribution in goats naturally affected with scrapie. J. Comp. Pathol., v.138, p. 90-101, 2008.

VACCARI, G.; PANAGIOTIDIS, C.H.; ACIN, C., et al. State-of-the-art review of goat TSE in the European Union, with special emphasis on PRNP genetics and epidemiology. Vet. Res. v.40, p.48, 2009.

WHITE, S.N.; REYNOLDS, J.O.; WALDRON, D.F. et al. Extended scrapie incubation time in goats singly heterozygous for PRNP S146 or K222. Gene, v.501, p.49-51, 2012. 